\title{
СОЦІАЛЬНО-ПСИХОЛОГІЧНІ ОСОБЛИВОСТІ ЕЛЕКТОРАЛЬНОГО ВИБОРУ
}

У статті здійснюється аналіз провідних наукових концепцій, в яких розкрито детермінанти електорального вибору. Подано результати емпіричного дослідження сочіально-психологічних чинників $i$ механізмів, щзо визначають характер політичного волевиявлення громадян. Обгрунтовано основні психологічні умови для здійснення електоратом компетентного політичного вибору.

Ключові слова: електоральна поведінка, електоральний вибір, вибори, вибориі, політичне волевиявлення.

Дослідження електоральної поведінки виборців є одним із актуальних завдань вітчизняної політичної психології, яке має вагоме теоретичне і прикладне значення. Політичні вибори є важливим суспільним процесом, що визначає майбутнє держави, головною формою вияву ролі народу й окремого індивіда як суб'єктів політики. Основне призначення виборів полягає у відображенні політичної волі членів суспільства щодо формування політичної влади і її легітимізації.

Рядові учасники виборчого процесу, природно, відрізняються неоднаковою участю в суспільно-політичному житті держави та рівнем електоральної активності. Однак сьогодні частка населення, що відмовляється брати участь у виборах, є значною в багатьох країнах, у тому числі й у тих, що характеризуються стабільною демократичною системою. Розчарування багатьох людей у політиці, яке зараз спостерігаємо, призводить до їх політичної пасивності, політичного відчуження або ж до протестного голосування. Сам вибір, який здійснюється сучасним виборцем, часто є недостатньо осмисленим і зваженим.

Водночас стан тривалої нестабільності, що спостерігається зараз не тільки в українській, але й загалом у світовій політиці, вимагає активної і свідомої участі населення в політичних процесах. Відповідно, виникає потреба в грунтовному розгляді психологічних чинників, що зумовлюють прийняття виборцями рішення про голосування i реалізацію ними електорального вибору, критеріїв і механізмів цього вибору, особливостей формування і трансформації електоральних установок. Це дозволить не тільки проаналізувати ключові детермінанти політичного вибору, але й спрогнозувати основні тенденції політичної поведінки електорату.

Метою нашого дослідження є теоретичний аналіз та емпіричне вивчення соціально-психологічних чинників та механізмів електорального вибору.

Виклад основних положень. Електоральний вибір - це дія виборця, якою він делегує владні повноваження одному із кандидатів на виборну посаду. Таке обрання депутата, політичного лідера або партії є різновидом політичного вибору і найважливішою складовою електоральної поведінки, а водночас і основним об'єктом уваги політтехнологів.

Прихильники різних наукових підходів, які прямо або дотично зачіпають проблему електоральної поведінки, по-різному пояснюють причини й механізми політичного вибору громадян. Зокрема, представники соціологічного підходу розглядають залежність електорального вибору насамперед від соціального статусу виборців.

Група американських вчених під керівництвом П. Лазарсфельда в середині XX ст. зробила висновок про те, що головними механізмом електоральної активності є ідентифікація виборців із референтними соціальними групами. Дослідники з'ясували, що на голосування індивіда суттєво впливають релігійна приналежність, соціальний клас, сім'я, стосунки на робочому місці, місцеві групи тиску, масові засоби комунікації, соціальноекономічний статус та інші чинники. Сам акт голосування розглядався як вияв солідарності індивіда з групою, тобто фактично йшлося про групові норми голосування й вияви 
конформності виборця щодо позиції референтної для нього соціальної спільності [16].

Американські дослідники С. Ліпсет і С. Роккан обгрунтували ідею про вплив соціальних конфліктів на партійну ідентифікацію виборців. Вчені виокремили чотири типи конфліктів у суспільстві, які особливо серйозно позначаються на електоральній поведінці: між центром і периферією, між державою і церквою, між містом і селом, між буржуазією (власниками) і робітничим класом. Кожен з цих конфліктів створює "розкол” у суспільстві, що визначає структурування підтримки партій і кандидатів [8]. Наприклад, у тих випадках, коли суспільство розділене за релігійною або етнічною ознакою, домінуючими стають конфесійні або етнічні чинники. Причому С. Ліпсет та С. Роккан зауважують, що в кожній політичній системі існує власна ієрархія ліній поділів, які можуть 3 часом змінюватися [8].

Таким чином, представники соціологічного підходу наблизилися до соціальнопсихологічних детермінант електоральної поведінки. Однак, зважаючи на той факт, що в умовах політичного плюралізму жодна соціальна група усім складом не вибирає єдину політичну орієнтацію, доцільно говорити тільки про наявність певних тенденцій політичного голосування представників певних соціальних груп.

Прихильниками соціально-психологічного підходу електоральна поведінка також розглядається як переважно експресивна, а провідним механізмом електорального самовизначення виборців вважається партійна або політична ідентифікація. Науковці 3 Мічиганського університету А. Кемпбелл, Ф. Конверс, В. Міллер та Д. Стоукс розробили модель “лійки причинності”, в якій розкрили структуру й ієрархію чинників електорального вибору [11]. Дослідники запропонували уявити вісь “лійки”, наповненої різними подіями, у вигляді часового виміру. У найширшій частині “лійки" містяться економічна структура, соціальні розколи й історичні традиції, які, хоч і не детермінують безпосередньо електоральний вибір, проте впливають на структуру партійної системи та формують наступний рівень факторів: групову лояльність і ціннісні орієнтації. Безпосередньо на електоральний вибір впливають установки виборців щодо кандидатів, політичних курсів (питання зовнішньої і внутрішньої політики), групових інтересів та проурядових партій. Також вчені виділяють низку зовнішніх відносно “лійки” короткотермінових чинників, як-от: поточні політичні та економічні умови, особливості виборчої кампанії, дії уряду, вплив друзів, оточення та ЗМІ. У “лійці” партійна ідентифікація виконує роль своєрідного фільтра, що опосередковує вплив сукупності установок виборців щодо кандидатів, політичних курсів і групових “вигод”.

Згодом Ф. Конверс розробив теорію “нормального голосування”, у якій партійна ідентифікація вважається доволі стабільною і перманентно позначається на електоральному виборі. Зміни спостерігаються лише у випадку впливу на виборця сильних короткострокових факторів, таких як різка зміна поточної політичної й економічної ситуації, поява актуальних проблем під час виборчої кампанії тощо. Вчений стверджує, що масам загалом не вистачає структурованих систем переконань, що спостерігаються в політичних елітах. Ці дуже нестабільні політичні погляди він називає “не-аттитюдами" [13].

А. О'Касс розглядає електоральну психологію виборців, зосереджуючись на їх локусі контролю, усвідомленні ризику, пов'язаному з виборами і голосуванням, виборчому контролі та позитивному зовнішньому впливі як детермінантах задоволення політичною участю і стабільності голосування на виборах. Результати його досліджень показали, що локус контролю позначається на усвідомленні виборцями ризику та електорального контролю. А локус контролю та сприйнятий ризик впливають на прийняття виборчого рішення, що, у свою чергу, відбивається на оцінці виборчого контролю. Крім того, залучення до виборчих рішень і позитивний вплив обумовлюють рівень задоволення від голосування, наслідком чого є схильність до голосування за одного кандидата 
або партію протягом тривалого часу (стабільність поведінки голосування) [18]. Однак відкритим в даному напрямі досліджень залишається питання про можливість ідентифікації виборця з кількома партіями або відсутність партійної ідентифікації узагалі.

У рамках раціонально-інструментального підходу поведінка виборця трактується вже не як експресивна, а - дієва. Вибори вважаються інструментом для досягнення електоратом власних цілей. Зокрема, в роботі Е. Даунса “Економічна теорія демократії” виборець розглядається як споживач, який здійснює свій вибір, раціонально осмислюючи політичну ситуацію, керуючись власними інтересами, незважаючи на установки та вплив об'єктивних факторів. Такий індивід оцінює реальні кроки претендента, його досягнення, програмні позиції конкуруючих партій чи кандидатів з точки зору тих вигод, які він отримає у випадку перемоги кожного з них [14]. Виборець, який мислить раціонально, надає перевагу тому кандидату, що запропонує найбільше підтверджень ефективності своєї майбутньої політичної діяльності і здатності задовольнити інтереси електорату. Водночас вчений зауважує, що така модель може працювати лише за умови ідеальної поінформованості усіх учасників політичного процесу загалом, і виборчого процесу зокрема [14].

Згідно з теорією “ретроспективного голосування” М. Файоріни, основним чинником, який зумовлює політичну активність індивіда, виявляється його суб'єктивна оцінка власного економічного становища. Попри те, що виборець зовсім не є добре поінформованим і зацікавленим громадянином, проте він не перестає діяти раціонально. Мінімізуючи власні зусилля у пошуках інформації, він користується найбільш доступними даними, а саме - знанням особливостей власного економічного становища та економічної ситуації в країні. Приймаючи рішення, виборець може спиратися на позиції лідерів громадської думки. Незацікавленість в отриманні інформації про партії і кандидатів оцінюється дослідниками як прояв раціональності індивідів, які оцінюють втрати свого часу вище, ніж можливий дохід від інформованості про діяльність партій [15]. Але виборці прагнуть до максимальної реалізації власних інтересів, тому електоральний вибір фактично перетворюється на покарання або нагородження чинного уряду за ту економічну політику, яка проводилась протягом попередніх років. Таке голосування отримало назву ретроспективного. Шляхом суб'єктивного оцінювання ситуації виборець визначає, чи варто йому знову голосувати за чинного політика, чи краще “змінити” його на перспективнішого кандидата [15]. Р. Інглхарт також стверджує, що голосування й політичний вибір $\epsilon$ ретроспективним i егоцентричним. Виборець аналізує не тільки успіхи й невдачі політичної діяльності кандидата, але й свій особистий виграш [5].

Г. Кларк з колегами розробили “модель валентного голосування", яка грунтується на ідеї про те, що для виборців найбільше значення має т. зв. валентність політиків - здатність ефективно діяти в тих сферах політики, які найбільше турбують електорат. Виборці використовують поточну інформацію про діяльність лідерів та їхніх партій і діють раціонально, але прагнуть зменшення когнітивного навантаження. Електоральний вибір є результатом партійної ідентифікації й оцінки діяльності партій і лідерів в економічних та інших важливих сферах життєдіяльності суспільства. Менше значення має близькість позиції кандидата політичній позиції виборця. 3 цієї точки зору, політики повинні переконати виборців, що вони можуть розв'язати ті проблеми, що викликають найбільше занепокоєння в суспільстві [12].

Окрім концепцій ретроспективного голосування, існує також низка теорій перспективного голосування. Наприклад, у “споживчій моделі голосування”, розробленій $\mathrm{X}$. Хіммельвейт зі співавторами, центральними змінними $є$ потреби виборців та проблематика виборів (питання, запропоновані до вирішення конкуруючими політичними силами), що співвідносяться на політичному ринку як попит і пропозиція. Під час прийняття виборцем рішення ключовою ланкою $є$ сукупність переконань, яких він дотримується стосовно політики партій щодо окремих питань. Поведінка виборця $є$ 
інструментальною: він надає перевагу тій партії чи кандидату, що, як очікується, найкраще забезпечить реалізацію його інтересів у майбутньому. Він шукає найкраще співвідношення (або ж найменшу невідповідність) між своїми поглядами й уподобаннями та платформами політичних партій (Цит. за: [10]).

Загалом, теорії раціонального вибору призвели до значних змін у поглядах на самого виборця, перетворивши його на свідомого суб'єкта, який на підставі порівняння різних альтернатив за певними критеріями, зіставлення витрат і виграшу від своєї участі у виборах, приймає електоральне рішення. Проте концепції електоральної участі, розроблені представниками раціонально-інструментального підходу, не завжди враховували, що для здійснення справді компетентного вибору необхідно оперувати дуже великим об'ємом даних, які рядовий виборець не здатний ані зібрати, ані проаналізувати. Тому поняття “раціональності результату вибору" згодом змінюють на категорію “обмеженої раціональності процесу вироблення рішення". Також до недоліків згаданого підходу належать надмірне перебільшення раціональності індивіда, неврахування експресивних аспектів голосування, особливостей політичної культури, інституційних характеристик політичних систем різних країн.

Як певну противагу раціонально-поведінковим теоріям, американські дослідники С. Розенберг і П. Маккаферті розробили концепцію “ірраціонального вибору”. Автори встановили, що динаміка політичної участі електорату залежить від рівня значущості політичних виборів. Наприклад, явка громадян на вибори президента зазвичай виявляється вищою, ніж під час виборів до місцевих органів влади. Крім того, дослідники зауважили, що через упевненість у перемозі партії, яка вже раніше вигравала виборчі перегони, у виборців зникає відчуття необхідності й важливості для результату виборів власного голосу, тому відбувається т. зв. електоральна демобілізація [19]. Результати проведеного нами емпіричного дослідження особливостей політичної активності молоді підтвердили ці дані [1].

Маніпулятивний підхід до аналізу електоральної поведінки грунтується на уявленні про залежність ідейно-політичних позицій виборців від впливу на них ЗМІ та інститутів влади. Такий вплив фактично характеризується вченими як пропагандистський і маніпулятивний. Зокрема, П. Лазарсфельд, Б. Берельсон і В. Макфі у праці "Голосування. Дослідження процесу формування думок виборця під час президентської виборчої кампанії зробили акцент на визначальній ролі під час виборів суспільних інститутів (офіційних інститутів влади, політичних партій, профспілок), поточних політичних проблем, а також міжособистісних взаємодій [9].

Г. Лассуелл, У. Ліпман, Дж. Дьюї, М. Маклюен та інші прихильники маніпулятивного підходу у своїх роботах стверджують факт тотального впливу медіа на свідомість та поведінку людей. Однак відповідні дослідження останніх років спростовують цю точку зору. Їх результати доводять, що вплив пропаганди, навіть досить потужної, не є абсолютним. Дійсно, мас-медіа виступають одним із провідних чинників, які прямо або опосередковано впливають на формування індивідуальної та масової політичної свідомості. У період виборів різко збільшується потік політичної інформації, зокрема реклами й пропаганди, активізується політико-просвітницька робота в різних інститутах політичної соціалізації особистості, зростає кількість і якість політичних комунікацій. Однак рядовому виборцю властиво виступати не тільки об'єктом інформаційного впливу, але й бути реальним дієвим суб' єктом, здатним критично сприймати й аналізувати інформацію, усвідомлювати свої політичні інтереси, брати участь у формуванні політичного контенту “нових” медіа в режимі реального часу.

Г. Дилигенський зауважує, що про маніпулювання як домінуючий чинник формування політичних орієнтацій можна говорити лише стосовно тих ситуацій, в яких вплив усіх або більшості джерел соціально-політичних уявлень великих груп населення 
гомогенний, характеризується єдиною спрямованістю [2]. Отже, виборець стає суб'єктом впливу на електоральні процеси, якщо здобуває необхідні для якісного волевиявлення знання, здатний “фільтрувати” інформацію, виявляє власну політичну позицію, вважає себе спроможним змінювати політичне життя суспільства разом з іншими людьми.

Як бачимо, перелічені вище наукові концепції по-різному пояснюють детермінанти електоральної поведінки громадян. Окремі дослідники вказують на можливість інтеграції кількох наукових підходів. Скажімо, у книзі М. Льюіс-Бека і Т. Райса "Прогнозування виборів" серед чинників електорального вибору згадується партійна ідентифікація (характерна для соціально-психологічних теорій) та економічні умови (основний чинник в раціонально-інструментальних концепціях). Крім того, в модель прогнозування президентських виборів дослідники також вводять такі показники як привабливість кандидата, його фізичні характеристики, моральні якості та цінності [17].

П. Лазарсфельд, Б. Берельсон і В. Макфі, окрім пропагандистського впливу політичних інституцій на думку виборця (що вважається основним чинником електорального вибору в маніпулятивному підході), виокремлюють також такі чинники політичного волевиявлення, як соціально-економічний статус, етнічну та релігійну ідентичність виборця, роль соціальних груп, до яких належить індивід (що властиво для соціологічного підходу) [9].

В. Казміренко виділяє такі чотири типи характеру політичного вибору особистості:

- раціональний вибір як очікувана цінність можливих варіантів вибору;

- розумовий вибір як усвідомлення наслідків та перспектив вибору;

- інтуїтивний вибір із недостатнім ступенем розуміння цілей та наслідків вибору;

- емоційний вибір як опора на ті емоційні стани, що супроводжують процес вибору [7].

Таким чином, вивчення й узагальнення результатів досліджень представників різних наукових шкіл дозволяє всебічно проаналізувати електоральний вибір як політикопсихологічне явище і визначити психологічні умови для його здійснення. Вважаємо, що компетентний електоральний вибір особа може зробити лише за наявності політичного інтересу й відповідної мотивації, достатнього рівня політичної свідомості й самосвідомості, політичної культури й поінформованості, політичної активності, психологічної готовності до прийняття рішення суспільно-політичної ваги, почуття відповідальності за свою політичну участь.

Дослідники зауважують, що у випадку електорального вибору відповідальність можна розглядати з двох позицій: з одного боку, індивід відповідає за свої дії, пов'язані 3 виборами; $з$ другого боку, індивід, який здійснює акт вибору, делегує певні повноваження “об'єктові” вибору [3, с. 71].

Проблеми мотивації електорального вибору торкається $Є$. Ільїн, який розмежовує мотивацію участі в голосуванні та мотивацію голосування за того чи іншого кандидата. Вчений стверджує, що на участь у голосуванні впливають внутрішні мотиватори (політична активність, почуття громадянського обов'язку) і зовнішні фактори (політична реклама, “ефект приєднання до більшості”). Своєю чергою, на вибір конкретного кандидата впливають політична ідентифікація та політична віра, як внутрішні мотиватори, і діяльність “виробників соціального тиску” (агітаторів), як зовнішній фактор [4, с. 230]. Подібної точки зору дотримується й О. Лабковська, яка окрім переліченого Є. Ільїним, до зовнішньої мотивації додає діяльність “продуцентів соціального впливу” та законодавче регулювання виборів [4]. Проте, очевидно, що згадані автори насправді презентують не стільки мотиви електоральної поведінки, скільки класифікацію чинників, які впливають на електоральний вибір.

Виборець бере участь в електоральних процесах, керуючись патріотичними, ідеологічними, гедоністичними, традиційними та іншими мотивами. Слід зважати також на те, що соціально-політичні установки, які визначають поведінку сучасного електорату та 
прийняття ним політичних рішень, періодично змінюються відповідно до актуалізації в суспільстві тих чи інших проблем соціально-політичного значення.

Політична активність індивіда, як умова компетентного електорального вибору, передбачає визначення власних критеріїв прийняття політичного рішення, пошук та аналіз інформації з різних джерел про кандидатів і їх команду, ознайомлення з їх політичною програмою, участь у зустрічах 3 політиками, обговорення виборчої тематики у колі близького й дальшого оточення, надання будь-якої підтримки обраному кандидату або партії. Психологічна готовність до політичного волевиявлення передбачає наявність в індивіда сукупності електоральних установок, потреб, відповідних знань і вмінь, що забезпечують усвідомлення індивідом необхідності й ефективності свого вибору, а також здатність реалізувати своє електоральне рішення.

3 метою визначення психологічних особливостей електоральної поведінки виборців нами у 2018 р. було проведено письмове опитування (анкетування), в якому взяли участь 336 осіб віком від 20 до 83 років, мешканців Івано-Франківської, Тернопільської і Львівської областей. Питання анкети було згруповано відповідно до таких завдань: діагностика рівня та мотивації електоральної участі респондентів, аналіз соціально-психологічних чинників і механізмів електорального вибору.

Результати проведеного нами анкетування показали, що 66,7\% наших респондентів стабільно беруть участь у політичних виборах. 11,9\% зазначили, що їхня присутність на виборах залежить від ситуативних чинників (життєвих обставин, наявності часу, настрою, зайнятості іншими справами тощо). $21,4 \%$ опитаних зізналися, що здебільшого вони відмовляються від участі у виборчих процесах.

Аналіз мотивації електоральної активності тих респондентів, які є завзятими виборцями, показав, що 42,3\% 3 них розглядають голосування як свій громадянський обов'язок, усвідомлюють власну здатність вплинути на результати виборів. 35,6\% опитаних здійснюють електоральний вибір, щоб попередити виборчі маніпуляції їхніми бюлетенями; можна припустити, що частина 3 них буде здійснювати протестне голосування. 14,1\% потенційних виборців йдуть голосувати, керуючись особливостями політичної культури й традиціями свого населеного пункту, наслідуючи електоральну поведінку родичів, друзів або сусідів. Решта $8,1 \%$ респондентів не змогли визначити мотиви власної електоральної участі.

Для сучасного виборця основними джерелами інформації про передвиборчі перегони є ЗМІ та близьке оточення. Зокрема, 78\% наших респондентів вказали, що вони отримують відомості про учасників виборів, переглядаючи новинні телепередачі, 41,7\% - спецпроекти телевізійних каналів, а 25,6\% - політичні ток-шоу. 58,9\% опитаних нами виборців здобувають інформацію про політичні події з Інтернету, 25,6\% - з радіо, 29,8\% - 3 публікацій у пресі, 17,3\% - 3 різноманітних агітаційних матеріалів. 89,3\% респондентів постійно або іноді обговорюють політичні теми в колі своєї сім’ї та друзів. $24,4 \%$ виборців беруть участь у зустрічах 3 політиками. При цьому попередньою політичною діяльністю кандидата цікавляться лише 53,6\% опитаних нами учасників дослідження. Програму кандидата на виборну посаду аналізують тільки 32,7\% респондентів.

Вивчення соціально-психологічних чинників електоральної поведінки учасників нашого дослідження показало, що найбільш вагомим з них є вплив телебачення. Зокрема, $70,2 \%$ опитаних нами осіб зазначили, що різного роду телепередачі (новини, телевізійні спецпроекти, телешоу, документальні фільми та ін.) позначаються на їхньому рішенні щодо характеру голосування. Політична реклама $є$ важливим чинником електорального вибору для 18,5\% виборців, а ще $35,7 \%$ респондентів вказали, що політична реклама частково впливає на їхнє волевиявлення. $44 \%$ опитаних під час прийняття рішення щодо варіанту електорального вибору орієнтуються на поради членів сім’ї і родичів, а 24,1\% 
респондентів - на позицію друзів, знайомих, 18,1\% - на рейтинг кандидата (за результатами соціологічних опитувань).

Також було з'ясовано, що на електоральний вибір впливає оцінювання виборцем ефективності попередньої громадсько-політичної діяльності кандидата на виборну посаду (на це вказали 38,9\% наших респондентів), відповідності програми кандидата актуальним інтересам суспільства та власним інтересам виборця $(31,6 \%)$, реалістичності обіцянок кандидата (40,5\%). 16,1\% виборців голосують під враженням від публічних зустрічей і взаємодії з кандидатами на виборні посади. 16,7\% опитаних не змогли більшменш чітко визначити чинники, які впливають на прийняття ними електорального рішення, що може свідчити про їхнє експресивне та інтуїтивне голосування.

Аналіз отриманих емпіричних даних також показав, що тільки 29,2\% наших респондентів вважають себе здатними впливати на політичні процеси в Україні. 24,4\% опитаних не визнають власної можливості впливу на вітчизняну політику. 46,4\% учасників дослідження не визначилися в цьому питанні. Ці дані дозволяють припустити, що більш, ніж дві третини виборців не визнають власну політичну суб'єктність. При цьому відповідальними за покращення чи погіршення політичної ситуації в Україні вважають себе лише 33,9\% наших респондентів, а свою часткову причетність до політики визнають $22,6 \%$ опитаних. $43,5 \%$ виборців знімають із себе будь-яку відповідальність за політичні події у своїй країні, повність покладаючи ії на політиків. Це дозволяє припустити, що виборці, які не усвідомлюють своєї здатності впливати на політичні події і процеси в державі і не відчувають власної відповідальності за свою участь в голосуванні й безпосередньо за свій електоральний вибір, легковажно ставляться до виконання своєї соціальної ролі виборця.

Висновки. Виконуючи роль виборця, кожен індивід, що досяг повноліття, виявляє свою політичну суб'єктність. Електоральний вибір є найважливішою складовою електоральної діяльності виборця, якою він делегує владні повноваження одному із кандидатів на виборну посаду.

Узагальнення результатів наших наукових розвідок та проведеного емпіричного дослідження дає можливість зробити висновок про те, що основними психологічними механізмами, які відіграють істотну роль у процесі електорального вибору є такі, як: конформізм виборця унаслідок тиску 3 боку мас-медіа, політичних інституцій та референтних груп, раціоналізація, ідентифікація виборців із референтними соціальними групами і наслідування їхнього вибору під час голосування, ідентифікація з кандидатами та ін.

Внаслідок опитування було з'ясовано, що дві третини респондентів є активними виборцями. Натомість кожен п'ятий учасник із нашої вибірки, як виявилося, зазвичай відмовляється від виконання ролі виборця. Абсентеїзм може розглядатися і як пасивний протест населення проти чинного політичного режиму, і як вияв байдужості до політичного життя, до виконання свого громадянського обов'язку.

Сучасні виборці отримують інформацію про передвиборчі перегони й кандидатів на виборні посади із різних джерел, найбільш важливими з яких є ЗМІ та близьке оточення виборця. Вагоме значення для характеру політичного волевиявлення громадян мають такі соціально-психологічні чинники, як: вплив ЗМІ (головно, телебачення), особливості політичної соціалізації особистості, політичні (в тому числі й електоральні) настанови, суб' єктивне оцінювання виборцями актуальної суспільно-політичної ситуації та попередньої громадської або політичної діяльності кандидатів, рівень політичної свідомості й самосвідомості електорату, певні соціокультурні аспекти, інтереси й потреби виборця, пов'язані з політикою, рівень довіри виборців до передвиборчих зобов'язань кандидата тощо.

Водночас, як показали дані анкетування, тільки третя частина наших респондентів 
вважають себе здатними впливати на політичні процеси в нашій країні і усвідомлюють свою відповідальність за характер голосування. Натомість дві третини учасників дослідження не відчувають власної причетності щодо політичних процесів у своїй державі. Майже половина опитаних нами виборців не визнають жодної власної відповідальності за політичні процеси в державі, а разом 3 тим - і за свій електоральний вибір. 3 наведених даних можемо зробити висновок про невисокий рівень політичної самосвідомості значної частини вітчизняних виборців, їх недовіру до результатів виборів, низьку зацікавленість у критичному аналізі отриманої інформації про кандидатів на виборні посади.

Прийняти компетентне електоральне рішення особа може за наявності достатнього рівня політичної свідомості й самосвідомості, здатності чітко визначати критерії власного політичного вибору, поінформованості щодо особливостей протікання виборчих процесів, передвиборчих програм, особистих політичних компетентностей кандидатів на виборні посади, психологічної готовності до прийняття рішення суспільнополітичної ваги, почуття відповідальності за власну електоральну активність, зокрема й за характер свого вибору.

Перспективи подальших наукових досліджень в окресленому напрямку вбачаємо у вивченні вікових і гендерних особливостей електоральної поведінки виборців, розробці психологічних технологій оптимізації рівня та якості їх електоральної активності.

1. Вітюк Н. Р., Вітюк С. В. Політичні установки як чинник політичної активності студентської молоді. Збірник наукових праць: філософія, соціологія, психологія. Івано-Франківськ : Вид-во ДВНЗ “Прикарпатський національний університет імені Василя Стефаника", 2016. Вип. 21. С. 21-29.

2. Дилигенский Г. Г. Социально-политическая психология : учеб. пособие для студ. вузов. Москва : Новая школа, 1996. $351 \mathrm{c}$.

3. Духневич В. Психологічна готовність до політичного вибору. Соціальна психологія. 2004. № 2 (4). С. $70-76$.

4. Ильин Е. П. Мотивация и мотивы. Санкт Петербург : Питер, 2000. 512 с.

5. Инглхарт Р. Культура и демократия. Политология: хрестоматия / [сост. Б. А. Исаев, А. С. Тургаев, А. Е. Хренов]. Санкт Петербург : Питер, 2006. С. 301-312.

6. Лабковская Е. Б. Психологические детерминанты поведения избирателей в ситуации политических виборов : автореф. дис. ... канд. психол. наук : 19.00.05. Санкт Петербург, 1996. 21 с.

7. Позняк Д. Соціально-психологічні механізми політичної свідомості виборців. Соціальна психологія. 2004. № 1 (3). С. 31-45.

8. Липсет С. М., Роккан С. Структуры размежеваний, партийные системы и предпочтения избирателей. Политическая наука. 2004. № 4. С. 204-234.

9. Berelson B. R., Lazarsfeld P. F., McPhee W. N. Voting: A Study of Opinion Formation in a Presidential Campaign. Chicago : The University of Chicago Press, 1986. 395 p.

10. Bull P. How voters decide. URL: https://thepsychologist.bps.org.uk/volume-18/edition-5/how-voters-decide.

11. Campbell A., Converse P. E., Miller W.E., Stokes D. E. The American Voter. URL: https://books. google.com.ua/books?hl=es\&lr=\&id=JeYUrs_GOcMC\&oi=fnd\&pg= PA18\&dq=the+american+voter+campbell\&ots.

12. Clarke H. D., Sanders D., Stewart M. C., Whiteley P. F. Valence Politics and Electoral Choice in Britain, 2010. URL: http://bes2009-10.org/papers/electoralchoice2010.pdf.

13. Converse P. E. Attitudes and non-attitudes: continuation of a dialogue. The quantitative analysis of social problems / E. R. Tufte, ed. Boston, MA : Addison-Wesley. 1970. P. 168-189.

14. Downs A. An Economic Theory of Democracy. URL: http://polisci2.ucsd.edu/foundation/documents/ 06Downs 1957.pdf.

15. Fiorina M. P. Voting behaviour. Perspectives on public choice : A handbook / ed. Dennis C. Mueller. New York : Cambridge university press, 1997. P. 391-414.

16. Lazarsfeld P. F., Berelson B., Gaudet H. The People's Choice : How the Voter Makes up His Mind in a Presidential Campaign. URL: peopleschoice\%20.pdf.

17. Lewis-Beck M. S., Rice T. W. Forecasting Elections. Washington : Congressional quarterly press, 1992.164 p.

18. O'Cass A. Electoral Choice. The Effect of Voter Control and Involvement on Satisfaction and Voting Stability. Journal of Political Marketing. 2003. Vol. 3. P. 61-85. 
Rosenberg S. W., Bohan L., McCafferty P., Harris K. The Image and the Vote: The Effect Of Candidate Representation on the Voter Preference. American Journal of Political Science. 1986. Vol. 30. P. $108-127$. 